\title{
PENGGUNAAN BUNGKIL INTI SAWIT YANG DIBERI HEMICELL DALAM RANSUM TERHADAP ENERGI METABOLISME RANSUM ITIK RAJA
}

\author{
(Utilization of palm kernel cake which is mixed with hemicell in the ration on feed \\ metabolizable energy of raja duck)
}

Elman Halawa, Iskandar Sembiring, Nurzainah Ginting

Program Studi Peternakan Fakultas Pertanian Universitas Sumatera Utara

\begin{abstract}
Palm kernel cake as one of potential alternative feed stuff that contain good enough nutritions. Palm kernel cake has a high content of crude fiber, so, it needs to be treated to improve quality. Using of hemicell on palm kernel cake is expected to decrease crude fiber content of palm kernel cake, which can improve the quality of rations and improve nitrogen retention, energy metabolism and conversion energy nitrogen metabolism corrected from gross energy on Raja duck. Research design used complete randomized design with five treatments and four replications. The treatments consist of RO (without palm kernel cake which is mixed with hemicell), R1 (5\% palm kernel cake which is mixed with hemicell), R2 (10\% palm kernel cake which is mixed with hemicell), R3 (15\% palm kernel cake which is mixed with hemicell), R4 (20 palm kernel cake which is mixed with hemicell). The variables were observed were average digestible of crude fiber, retention nitrogen and metabolism energy on Raja duck. The results showed that the treatments give not significant difference $(P<0,05)$ of retention nitrogen, metabolizable energy and conversion metabolism energy corrected by nitrogen on Raja duck. The use of palm kernel cake were given hemicell $2 \mathrm{cc} / \mathrm{kg}$ can given to the level of $20 \%$ as the material ration raja duck 7 week age.
\end{abstract}

Keywords: Palm kernel cake, Hemicell ${ }^{\circledR}$, Raja duck, Metabolizable Energy

\begin{abstract}
ABSTRAK
Bungkil inti sawit adalah salah satu alternatif bahan pakan yang mempunyai nutrisi yang cukup baik. Bungkil inti sawit mempunyai serat kasar yang tinggi, sehingga perlu perlakuan untuk memperbaiki kualitasnya. Penggunaan hemicell terhadap bungkil inti sawit dapat mengurangi kandungan serat kasarnya sehingga dapat memperbaiki kualitas pakan dan meningkatkan retensi nitrogen, energi metabolisme dan konversi energi metabolisme dari energi bruto itik raja. Rancangan penelitian yang digunakan adalah rancangan acak lengkap dengan 5 perlakuan dan 4 ulangan. Ransum yang digunakan adalah ransum buatan sendiri yaitu R0 (tanpa bungkil inti sawit yang diberi hemicell), R1 (5\% bungkil inti sawit yang diberi hemicell), R2 (10\% bungkil inti sawit yang diberi hemicell), R3 (15\% bungkil inti sawit yang diberi hemicell), R4 (20\% bungkil inti sawit yang diberi hemicell). Parameter yang diamati adalah retensi nitrogen, energi metabolisme dan konversi energi metabolisme dari energi bruto itik raja. Hasil penelitian menunjukan bahwa perlakuan memberikan pengaruh tidak berbeda nyata $(\mathrm{P}<0,05)$ terhadap retensi nitrogen, energi metabolisme (semi, murni, semi terkoreksi nitrogen dan murni terkoreksi nitrogen) dan konversi energi metabolisme dari energi bruto ransum. Penggunaan bungkil inti sawit yang diberi hemicell $2 \mathrm{cc} / \mathrm{kg}$ dapat diberikan sampai level $20 \%$ sebagai bahan penyusun ransum itik Raja umur 7 minggu.
\end{abstract}

Kata kunci: Bungkil inti sawit, Hemicell, itik Raja, Energi Metabolisme

\section{PENDAHULUAN}

Peternakan unggas saat ini berkembang dengan pesat dan sudah diklasifikasikan sebagai industri biologis. Dalam industri biologis terjadi interaksi empat variabel yang tidak dapat dipisahkan yaitu: peternak sebagai subyek yang harus dijamin meningkat pendapatan dan kesejahteraannya, ternak sebagai obyek yang ditingkatkan produksinya, lahan basis 
ekologi yang mendukung pakan dan lingkungan budidaya, serta teknologi sebagai alat/rekayasa untuk mencapai tujuan.

Menurut Badan Pusat Statistis (2007) populasi unggas khususnya ayam pedaging, ayam petelur dan itik pedaging terjadi peningkatan, hal ini dikarenakan produknya yang disukai dan dikonsumsi oleh masyarakat Indonesia karena merupakan sumber gizi yang baik, rasanya enak dan harganya relatif murah. Di samping itu, keberhasilan industri perunggasan ini selain ditopang oleh penguasaan manajemen beternak dan pengadaan bibit yang baik juga di imbangi dengan penyediaan ransum yang berkualitas. Sedemikian penting peranan ransum pada peternakan unggas sehingga biaya tersebut mencapai $70-80 \%$ dari total biaya produksi.

Untuk mengurangi biaya pakan perlu memanfaatkan pakan alternatif yang merupakan produk sumber daya alam Indonesia berupa Limbah perkebunan dan hasil ikutannya dari pabrik minyak kelapa sawit yang tersedia relatif banyak sepanjang tahun seperti Bungkil Inti Sawit (BIS). BIS sampai saat ini belum dimanfaatkan secara optimal karena adanya kendala yang terkandung didalamnya yakni serat kasar dan lignin yang tinggi sehingga sulit dicerna oleh ternak terutama ternak monogastrik.

Bungkil inti sawit memiliki kandungan zat-zat makanan sebagai berikut: Protein kasar 15,14\%; lemak kasar 6,08\%; serat kasar 17,18\%; kalsium 0,47\%; fosfor $0,72 \%$, dan BETN 57,80\% serta kandungan energi brutonya adalah 5088 kkal/kg (Lab. Kimia Makanan Ternak Unpad, 2004).

Perkembangan teknologi di bidang pengolahan bahan makanan yang ada saat ini dapat diterapkan untuk meningkatkan kualitas limbah argoindustri menjadi bahan pakan yang bermutu, yaitu dengan sentuhan bioteknologi. Sementara itu, proses biokonversi substrat limbah perkebunan kelapa sawit melalui fermentasi menawarkan alternatif yang menarik dan bermanfaat dalam pengembangan sumber bahan baku untuk ransum unggas, namun telah banyak dilakukan dan mempunyai tingkat kesulitan aplikasinya di lapangan, akhir- akhir ini berkembang teknologi inkubasi dengan penambahan imbuhan pakan untuk memperbaiki kualitas bahan pakan. Dalam hal ini makanan tambahan yang digunakan adalah enzim yang dapat membantu pencernaan. Peranan enzim dalam saluran pencernaan ditujukan terhadap pencernaan pati, lemak dan protein (Wahyu, 1992). Enzim yang digunakan adalah enzim Hemicell $^{\circledR}$ hasil fermentasi dari Bacillus lentus. Hasil analisa kimia menunjukkan bahwa enzim hemicell ini efektif menghancurkan $\beta$-Mannan dalam bahan makanan, serta meningkatkan keseragaman kawanan ternak, dapat mengurangi stres, meningkatkan kekebalan pada hewan dan membantu proses pencernaan (Chemgen, 1999). 
Pengukuran kualitas bahan pakan bungkil inti sawit dapat dilakukan melalui pengujian secara biologis. Salah satu uji biologis yang dapat dilakukan adalah dengan cara penentuan nilai kecernaan, baik kecernaan bahan kering, bahan organik maupun kecernaan protein kasar pada bungkil inti sawit. Pengukuran nilai kecernaan pada ternak itik sangatlah tepat karena unggas air memiliki kemampuan dalam mencerna pakan berserat kasar tinggi, penyerapan zat-zat makanan dapat terlihat, serta tergolong ternak yang efisien dalam menggunakan pakan. Oleh karena itu, itik sangat tepat dijadikan ternak percobaan untuk menguji kualitas pakan dari limbah industri sawit seperti bungkil inti sawit. Penggunaan bungkil inti sawit dalam pakan diharapkan dapat menigkatkan respon positif dalam menunjang pertumbuhan dan produksi itik pedaging.

Prinsip penentuan kecernaan zat-zat makanan adalah menghitung banyaknya zat-zat makanan yang dikonsumsi dikurangi dengan banyaknya zat-zat makanan yang dikeluarkan melalui feses. Semakin baik kualitas pakan maka semakin baik pula daya cerna pakan tersebut, sehingga penyerapan kandungan nutrisinya lebih optimal. Adapun tujuan penelitian ini adalah untuk mengetahui pengaruh penggunaan bungkil inti sawit yang diberi hemicell dalam ransum terhadap energi metabolisme ransum itik Raja umur 7 minggu.

\section{BAHAN DAN METODE}

\section{Tempat dan Waktu Penelitian}

Penelitian dilaksanakan di Laboratorium Biologi Ternak, Jln. Prof. Dr. A. Sofyan No 3, Program Studi Peternakan Fakultas Pertanian Universitas Sumatera Utara. Penelitian ini dilaksanakan selama 49 hari dari bulan Juli 2011 sampai bulan Agustus 2011.

\section{Bahan dan Alat Penelitian}

\section{Bahan}

Adapun bahan-bahan yang digunakan dalam penelitian adalah itik Raja umur 7 minggu sebanyak 20 ekor. Bahan penyusun ransum terdiri dari bungkil inti sawit, hemicell, jagung, dedak padi, bungkil kelapa, bungkil kedelai, tepung ikan, minyak nabati, Top Mix. Air minum untuk memenuhi kebutuhan air dalam tubuh. Air gula untuk mengurangi stress dari kelelahan transportasi. Rodalon sebagai desinfektan kandang dan peralatan tempat pakan dan minum. Formalin $40 \%$ dan $\mathrm{KMnO}_{4}$ (Kalium permanganate) untuk fumigasi kandang. Vitamin dan suplemen tambahan seperti Ciami. 


\begin{abstract}
Alat
Kandang yang digunakan pada saat pengumpulan sampel untuk penentuan retensi nitrogen, energi metabolis dan daya cerna serat kasar adalah kandang biologis berukuran $52 \mathrm{x}$ 25 x $45 \mathrm{~cm}$ sebanyak 20 buah dengan teknik pemberian ransum secara paksa (force feeding). Masing-masing kandang terdiri dari 1 ekor itik MA. Kandang ini dilengkapi tempat air minum serta plastik penampung ekskreta. Peralatan lain yang digunakan adalah timbangan digital dengan skala $2 \mathrm{~kg}$ dengan ketelitian $2 \mathrm{~g}$, oven $60{ }^{\circ} \mathrm{C}$, freezer, $\mathrm{H}_{2} \mathrm{SO}_{4} 0,01 \mathrm{~N}$, label, sendok dan kantong plastik. Alat penerang dan pemanas berupa lampu pijar 40 watt sebanyak 20 buah. Thermometer sebagai pengukur suhu kandang. Alat pencatat data seperti buku data, alat tulis dan kalkulator. Alat pembersih kandang berupa sapu, sekop dan hand sprayer. Alat lain berupa ember dan pisau.
\end{abstract}

\title{
Metode Penelitian
}

Adapun metode penelitian yang digunakan adalah rancangan acak lengkap (RAL) dengan 5 perlakuan dan 4 ulangan, setiap ulangan terdiri atas 5 ekor. Dengan perlakuan pemberian ransum, yaitu:

$\mathrm{R} 0=$ ransum tanpa penggunaan BIS dan hemicell.

$\mathrm{R} 1=$ ransum dengan penggunaan $5 \%$ BIS yang diberi hemicell $2 \mathrm{cc} / \mathrm{kg}$.

$\mathrm{R} 2=$ ransum dengan penggunaan $10 \%$ BIS yang diberi hemicell $2 \mathrm{cc} / \mathrm{kg}$.

$\mathrm{R} 3=$ ransum dengan penggunaan $15 \%$ BIS yang diberi hemicell $2 \mathrm{cc} / \mathrm{kg}$.

$\mathrm{R} 4=$ ransum dengan penggunaan $20 \%$ BIS yang diberi hemicell $2 \mathrm{cc} / \mathrm{kg}$.

\section{Peubah yang di amati}

\section{Retensi Nitrogen (\%)}

Retensi nitrogen diperoleh dengan melakukan pengukuran protein kasar ransum, endogenous dan ekskreta itik (Sibbald dan Wolynetz, 1985). Retensi nitrogen menunjukkan nilai nitrogen yang digunakan oleh tubuh ternak. Nilai ini dapat diperoleh dari selisih antara nilai konsumsi protein kasar (KP) dengan nilai protein yang diekskresikan (EP) setelah dikoreksi dengan nilai ekskresi protein endogenous (ENP). Dengan kata lain retensi nitrogen (RN) yaitu selisih antara nilai konsumsi protein kasar dengan nilai protein kasar yang diekskresikan setelah dikoreksi dengan nilai ekskresi protein endogenous.

\section{Energi Metabolisme (kkal/kg)}


Energi metabolisme adalah selisih antara kandungan energi bruto ransum dengan energi bruto yang hilang melalui ekskreta. Energi metabolisme dinyatakan dengan 4 peubah (Sibbald dan Wolynetz, 1985) yaitu:

a. Energi Metabolisme Semu (EMS) (kkal/kg).

b. Energi Metabolisme Murni (EMM) (kkal/kg).

c. Energi Metabolisme Semu Terkoreksi Nitrogen (EMSn) (kkal/kg).

d. Energi Metabolisme Murni Terkoreksi Nitrogen (EMMn) (kkal/kg).

\section{Konversi EMSn/EB}

Daya cerna energi bukan ditentukan oleh nilai energi metabolisme baik semu (EMS), murni (EMM), semu terkoreksi nitrogen (EMSn) ataupun murni terkoreksi nitrogen (EMMn), akan tetapi ditentukan oleh konversi EMSn terhadap energi bruto atau rasio EM/EB ransum.

\section{Prosedur Pengambilan/Pengolahan Data}

1. Berat Ekskreta (g/ekor)

Berat ekskreta diperoleh setelah ekskreta dikeringkan dalam oven $60^{\circ} \mathrm{C}$.

2. Energi Bruto Ekskreta/EB (kkal/kg)

Energi bruto ekskreta diperoleh dari analisis energi menggunakan bomb kalorimeter.

3. Konsumsi Protein Kasar/KP (g/ekor)

Konsumsi protein kasar merupakan hasil perkalian dari jumlah ransum yang dikonsumsi (K) dengan kandungan protein kasarnya (PK).

4. Protein Kasar Ekskreta/EP (g/ekor)

Nitrogen ekskreta diperoleh dari analisis protein kasar laboratorium.

5. Protein Kasar Endogenous/ENP (g/ekor)

Protein kasar endogenous diperoleh dari analisis protein kasar laboratorium.

\section{HASIL DAN PEMBAHASAN}

\section{Retensi Nitrogen}

Retensi nitrogen adalah hasil pengurangan nitrogen dalam ransum yang dikonsumsi dengan nitrogen yang hilang melalui ekskreta (Sibbald dan Wolynetz, 1985). Perbedaan level bungkil inti sawit yang diberi perlakuan hemicell ${ }^{(\mathrm{R})}$ pada itik Raja menghasilkan nilai retensi nitrogen yang tidak berbeda. Dari rataan retensi nitrogen sebesar 87,33\% dan tertinggi ditunjukan oleh perlakuan R1 sebesar $88,62 \%$ sedangkan terendah diperoleh dari perlakuan R4 sebesar 85,63\%. Hasil penelitian disajikan pada Tabel 1 .

Analisis keragaman retensi nitrogen menunjukan bahwa perbedaan bungkil inti sawit yang telah diberi perlakuan hemicell $^{(\mathrm{R})}$ dalam ransum memberikan pengaruh yang tidak berbeda nyata terhadap retensi nitrogen. Sekalipun nilai retensi nitrogen dari semua perlakuan 
menunjukan hasil yang tidak berbeda nyata. Namun dapat dilihat bahwa retensi nitrogen yang diperlihatkan ransum perlakuan R1 lebih tinggi dari nilai retensi nitrogen perlakuan lainnya. Perbedaan nilai retensi nitrogen ini menunjukan bahwa penggunan hemicell ${ }^{\circledR}$ pada level BIS 5\% dapat meningkatkan retensi nitrogen itik Raja umur 7 minggu. Kandungan nutrisi ransum perlakuan R1 lebih baik dari kandungan ransum perlakuan lainnya tetapi tidak memberi pengaruh yang berbeda terhadap tingkat konsumsi ransum itik Raja tetapi dari hasil yang diperoleh bahwa R1 menunjukkan rataan tertinggi pada persentase nitrogen sehingga yang diretensi semakin tinggi. Dibandingkan dengan rataan ransum perlakuan lainnya dengan kandungan nutrisi yang lebih rendah sehingga nilai nitrogen yang diretensi semakin rendah pula. Hal ini sesuai dengan pernyataan Wahyu (1992) yang menyatakan bahwa konsumsi ransum dapat dipengaruhi oleh defisiensi zat makanan. Semakin baik kualitas suatu ransum, maka semakin baik pula tingkat konsumsi ransumnya. Didukung juga oleh NRC (1994) yang menyatakan bahwa nilai retensi nitrogen dapat berbeda dikarenakan faktor nutrisi ransum yang berbeda pula. Semakin tinggi tingkat konsumsi ransum itik maka semakin tinggi pula persentase nitrogen yang diretensi. Hal ini terlihat dari ekskreta yang mengandung sedikit nitrogen urin dan energi dibandingkan dengan ternak yang tidak meretensi nitrogen.

Tabel 1. Pengaruh penambahan hemicell pada ransum.

\begin{tabular}{|c|c|c|c|c|c|}
\hline \multirow{2}{*}{$\begin{array}{l}\text { Peubah yang } \\
\text { diamati }\end{array}$} & \multicolumn{5}{|c|}{ Perlakuan } \\
\hline & R0 & R1 & R2 & R3 & R4 \\
\hline $\begin{array}{l}\text { Retensi nitrogen } \\
(\%)\end{array}$ & $88,35 \pm 2,46^{\mathrm{a}}$ & $88,62 \pm 1,19^{a}$ & $87,56 \pm 2,52^{a}$ & $86,49 \pm 1,10^{\mathrm{a}}$ & $85,63 \pm 2,66^{\mathrm{a}}$ \\
\hline $\begin{array}{l}\text { Energi metabolisme } \\
\text { semu }(\mathrm{kkal} / \mathrm{kg})\end{array}$ & $2.536,72 \pm 50,74^{\mathrm{a}}$ & $2.562,87 \pm 27,67^{\mathrm{a}}$ & $2.516,44 \pm 68,71^{\mathrm{a}}$ & $2.507,11 \pm 32,76^{\mathrm{a}}$ & $2.436,48 \pm 76,96^{\mathrm{a}}$ \\
\hline $\begin{array}{l}\text { Energi metabolisme } \\
\text { murni }(\mathrm{kkal} / \mathrm{kg})\end{array}$ & $2.602,94 \pm 50,74^{\mathrm{a}}$ & $2.630,18 \pm 27,67^{\mathrm{a}}$ & $2.590,34 \pm 68,71^{\mathrm{a}}$ & $2.587,96 \pm 28,13^{\mathrm{a}}$ & $2.515,74 \pm 76,96^{\mathrm{a}}$ \\
\hline $\begin{array}{l}\text { Energi metabolisme } \\
\text { semu terkoreksi } \\
\text { nitrogen }(\mathrm{kkal} / \mathrm{kg})\end{array}$ & $2.536,51 \pm 50,74^{\mathrm{a}}$ & $2.562,65 \pm 27,67^{\mathrm{a}}$ & $2.516,23 \pm 68,70^{\mathrm{a}}$ & $2.506,92 \pm 32,76^{\mathrm{a}}$ & $2.436,28 \pm 76,95^{\mathrm{a}}$ \\
\hline $\begin{array}{l}\text { Energi metabolisme } \\
\text { murni terkoreksi } \\
\text { nitrogen }(\mathrm{kkal} / \mathrm{kg})\end{array}$ & $2.602,73 \pm 50,74^{\mathrm{a}}$ & $2.629,96 \pm 27,67^{\mathrm{a}}$ & $2.590,14 \pm 68,70^{\mathrm{a}}$ & $2.590,46 \pm 32,76^{\mathrm{a}}$ & $2.515,55 \pm 76,95^{\mathrm{a}}$ \\
\hline Konversi EMSn/EB & $0,870 \pm 0,02^{\mathrm{a}}$ & $0,871 \pm 0,01^{\mathrm{a}}$ & $0,869 \pm 0,02^{\mathrm{a}}$ & $0,867 \pm 0,01^{\mathrm{a}}$ & $0,844 \pm 0,03^{\mathrm{a}}$ \\
\hline
\end{tabular}

\section{Energi metabolisme}

Energi metabolis (metabolizable energy) merupakan energi dari bahan pakan. Perhitungan energi metabolisme ransum dinyatakan dengan 4 peubah yaitu energi metabolisme semu, energi metabolisme murni, energi metabolisme semu terkoreksi nitrogen 
dan energi metabolisme murni terkoreksi nitrogen. Energi metabolis semu adalah energi bruto dikurangi energi ekskreta sedangkan energi metabolis yang memperhitungkan energi endrogen disebut energi yang sesungguhnya (Sibbald dan Wolynetz, 1985). EMS tidak memperhitung-kan metabolic faecal dan endogenous urinary (Sibbald, 1979).

\section{a. Energi Metabolisme Semu (EMS)}

Rataan energi metabolisme semu ransum itik Raja umur 7 minggu sebesar 2.511,92 $\mathrm{kkal} / \mathrm{kg}$. Energi metabolisme semu tertinggi ditunjukan oleh perlakuan R1 sebesar 2.562,87 $\mathrm{kkal} / \mathrm{kg}$, sedangkan energi metabolisme semu terendah diperoleh dari perlakuan R4 sebesar 2.436,48 kkal/kg. Analisis sidik ragam energi metabolisme semu menunjukan bahwa perbedaan level bungkil inti sawit yang diberi perlakuan hemicell $^{(\mathrm{R})}$ dalam ransum memberikan pengaruh yang tidak berbeda terhadap energi metabolisme baik semu (EMS) itik Raja umur 7 minggu.

b. Energi Metabolisme Murni (EMM)

Energi metabolisme murni (EMM) merupakan energi metabolisme yang memperhitungkan energi endogenous sebagai faktor koreksi (Sibbald, 1980). Hal ini menyebabkan nilai dari EMM lebih besar dari EMS. Rataan energi metabolisme murni ransum itik Raja umur 7 minggu sebesar 2.585,43 kkal/kg. Energi metabolisme murni tertinggi ditunjukan oleh perlakuan R1 sebesar 2.630,18 kkal/kg, sedangkan energi metabolisme murni terendah diperoleh dari perlakuan R4 sebesar $2.515,74 \mathrm{kkal} / \mathrm{kg}$.

Analisis sidik ragam energi metabolisme murni menunjukkan bahwa penggunaan bungkil inti sawit yang diberi hemicell ${ }^{(\mathrm{R})}$ memberikan pengaruh yang tidak berbeda nyata terhadap energi metabolisme murni (EMM) ransum itik Raja umur 7 minggu.

Ransum dengan nutrisi yang kompleks akan merangsang perkembangan organ saluran pencernaan, meningkatkan kapasitas pencernaan dan penyerapan usus. Dengan kata lain, itik yang diberikan ransum dengan kualitas yang baik akan memiliki organ pencernaan yang lebih baik, sehingga jumlah nutrisi yang diserap semakin banyak. Genetik seekor ternak dengan produktivitas yang baik akan memiliki organ pencernaan yang lebih berkembang dengan bertambahnya panjang usus, kepadatan dan tinggi vili-vili serta perubahan fisiologi (meningkatnya produksi pankreas dan enzim pencernaan) termasuk meningkatnya area permukaan pencernaan dan penyerapan. Hal ini sesuai dengan pernyataan Amrullah (2002) yang menyatakan bahwa jumlah energi yang dapat dimanfaatkan sewaktu ransum masuk ke tubuh unggas bergantung pada kualitas ransum yang diberikan. Besar kecilnya energi yang 
dimetabolis seekor ternak tergantung dari nutrisi yang terkandung dalam ransum. Proses pencernaan dan metabolisme dengan pertumbuhan ternak yang lebih tinggi akan mengolah lebih banyak senyawa kimia yang masuk menembus dinding usus menjadi energi yang tersedia, yang kemudian akan digunakan untuk berbagai keperluan baik untuk hidup pokok, aktivitas maupun untuk menghasilkan produk. Didukung juga oleh pernyataan NRC (1994) yang menyatakan bahwa besarnya konsumsi ransum pada berbagai umur tidak tetap. Jumlahnya bervariasi sesuai dengan laju pertumbuhan dan tingkat produksi atau dapat dikatakan kebutuhan energi seekor ternak selain dicerminkan dari jumlah konsumsi ransum, juga ditentukan dari pertambahan bobot badan per harinya. Kebutuhan energi akan semakin meningkat seiring dengan pertumbuhan yang cepat.

c. Energi Metabolisme Semu Terkoreksi Nitrogen (EMSn)

Nilai energi metabolisme semu terkoreksi nitrogen (EMSn) dan energi metabolisme murni terkoreksi nitrogen (EMMn) merupakan nilai energi metabolis yang dikoreksi dengan nitrogen Sibbald and Wolynetz (1985), sehingga nilainya lebih kecil dari EMS dan EMM.

Rataan energi metabolisme semu terkoreksi nitrogen (EMSn) ransum itik Raja umur 7 minggu sebesar 2.511,72 kkal/kg. Energi metabolisme semu terkoreksi nitrogen tertinggi ditunjukan oleh perlakuan R1 sebesar 2.562,65 kkal/kg sedangkan energi metabolisme semu terkoreksi nitrogen terendah diperoleh dari perlakuan R4 sebesar 2.436,28 kkal/kg. Daya cerna ransum yang tinggi ditunjukan dari tingginya nitrogen yang diretensi. Retensi nitrogen yang tinggi ini menunjukan bahwa tingkat konsumsi energi itik yang tinggi pula. Konsumsi energi yang tinggi tersebut memberikan gambaran bahwa tingkat energi metabolisme ransum yang tinggi. Hal ini sesuai dengan pendapat Storey dan Allen (1982) yang menyatakan bahwa semakin tinggi konsumsi energinya, maka energi metabolis semakin tinggi. Daya cerna merupakan faktor yang mempengaruhi energi metabolis ransum, daya cerna yang tinggi menyebabkan banyak energi yang terserap dan energi yang hilang melalui ekskreta semakin sedikit.

Analisis ragam yang diperoleh menunjukkan bahwa untuk penggunaan hemicell $^{\circledR}$ pada BIS dalam ransum tidak memberikan pengaruh yang tidak berbeda nyata. Dimana dari semua perlakuan yang diberikan kepada itik tersebut memberi pengaruh yang sama terhadap energi metabolisme semu terkoreksi nitrogen (EMSn). Hasil penelitian ini menunjukkan bahwa itik yang mendapat perlakuan pada R1 dengan penampilan akhir yang baik memberikan gambaran bahwa tingkat energi metabolismenya yang semakin tinggi. Hal ini 
sesuai NRC (1994) menjelaskan bahwa semakin bertambah umur dan bobot badan ternak, maka energi metabolisnya akan semakin tinggi.

d. Energi Metabolisme Murni Terkoreksi Nitrogen (EMMn)

Rataan energi metabolisme murni terkoreksi nitrogen (EMMn) ransum itik raja umur 7 minggu sebesar 2.585,77 kkal/kg. Energi metabolisme murni terkoreksi nitrogen itik Raja umur 7 minggu tertinggi ditunjukan oleh perlakuan R1 sebesar 2.629,96 kkal/kg, sedangkan energi metabolisme murni terkoreksi nitrogen terendah diperoleh dari perlakuan R4 sebesar $2.515,55 \mathrm{kkal} / \mathrm{kg}$.

Analisis ragam yang diperoleh menunjukkan bahwa untuk penggunaan hemicell $^{\circledR}$ pada BIS dalam ransum tidak memberikan pengaruh yang nyata terhadap energi metabolisme murni terkoreksi nitrogen, dimana semua perlakuan yang diberikan kepada itik tersebut memberi pengaruh yang sama terhadap energi metabolisme murni terkoreksi nitrogen (EMMn) ransum itik Raja umur 7 minggu.

\section{Konversi EMSn/EB}

Daya cerna energi bukan ditentukan oleh nilai energi metabolisme baik semu (EMS), murni (EMM), semu terkoreksi nitrogen (EMSn) ataupun murni terkoreksi nitrogen (EMMn), akan tetapi ditentukan oleh konversi EMSn terhadap energi bruto atau rasio EM/EB ransum.

Rasio EMSn/EB ransum tertinggi pada penelitian ini diperoleh dari itik yang mendapat perlakuan $\mathrm{R} 1$ sebesar $0,871 \pm 0,02$ dan rasio $\mathrm{EMSn} / \mathrm{EB}$ ransum terendah diperoleh pada perlakuan R4 sebesar $0,844 \pm 0,03$. Hasil sidik ragam menunjukkan bahwa pemberian perlakuan kepada ternak itik tidak memberikan pengaruh yang nyata dalam mempengaruhi konversi EMSn terhadap energi bruto ransum. Hal ini berarti, itik yang mendapatkan ransum semua perlakuan sama pengaruhnya terhadap efisiensi penggunaan energi bruto menjadi energi metabolis.

Pemberian ransum pada perlakuan R1 merupakan perlakuan yang paling efisien karena kandungan BIS yang diberi hemicell lebih sedikit dapat menggunakan energi bruto menjadi energi metabolis semaksimal mungkin. Hal ini disebabkan dari kandung serat kasarnya yang semakin sedikit.

Hasil penelitian baik retensi nitrogen, energi metabolisme semu, energi metabolisme murni, energi metabolisme semu terkoreksi nitrogen, energi metabolime murni terkoreksi nitrogen dan konversi EMSn terhadap energi bruto ransum dari keenam perlakuan dapat dilihat pada tabel 1 . 


\section{KESIMPULAN}

Berdasarkan hasil penelitian memperlihatkan bahwa penggunaan bungkil inti sawit yang diberi hemicell dalam ransum itik Raja (Mojosari Alabio) memberi pengaruh tidak berbeda nyata terhadap retensi nitrogen, energi metabolisme dan konversi EMSn/EB, sehingga penggunaan BIS yang diberi hemicell $2 \mathrm{cc} / \mathrm{kg}$ dapat diberikan sampai level 20\% sebagai bahan penyusun ransum itik Raja umur 7 minggu.

\section{DAFTAR PUSTAKA}

Amrullah, I. K. 2002. Nutrisi Ayam Broiler. Lembaga Satu Gunung Budi, Bogor.

BPS. Badan Pusat Statistik Indonesia. 2007. Peternakan Indonesia Dalam Angka. Jakarta: BPS Indonesia.

Chemgen. 1999. Hemicell Feed Enzyme. Analytical Chemistry Laboratory, USA.

Hanafiah, K.A., 2003. Rancangan Percobaan. Fakultas Pertanian, Universitas Sriwijaya, Palembang.

Laboratorium Kimia makan Ternak Unpad. 2004. Fakultas Peternakan. Universitas Padjadjaran. Sumedang.

Mc Donald, P., A. Edwards and J. F. D. Green Haigh. 1994. Animal Nutrition. $4^{\text {th }}$ Ed. Longman Scientific and Technical. Copublishing in The USA with John Wiley and Sons. Inc. New York.

National Research Council. 1994. Nutrient Requirements of Poultry Eighth Revised Edition. National Academy of Sciences. Washington, DC.

Sibbald, I. R. 1979. The Effect of The Drying Procedure on Drying Poultry Excreta. Poultry Sci., 58 : 1392 - 1394.

Sibbald, I. R. 1980. Metabolic Plus Endogenous Energy and Nitrogen Losses of Adult Cockerels : The Correction Used in Bioassay for True Metabolizable Energy. Poultry Sci. $60: 805-811$.

Sibbald, I. R. and M. S. Wolynetz. 1985. Estimates of Retained Nitrogen Used to Correct Estimates of Bioavailable Energy. Poultry Sci., 64 : 1506 - 1513.

Storey, M. L. and N. K. Allen. 1982. Apparent and True Metabolizable Energy of Feedingstuffs For Manure, Non Laying Female Ambden Geese. Poultry Sci. 60 : 739 - 747.

Wahyu. J. 1992. IImu Nutrisi Ternak Unggas. UGM-Press, Yogyakarta. 